ANDRZEJ JACEK NaJda

UKSW w Warszawa

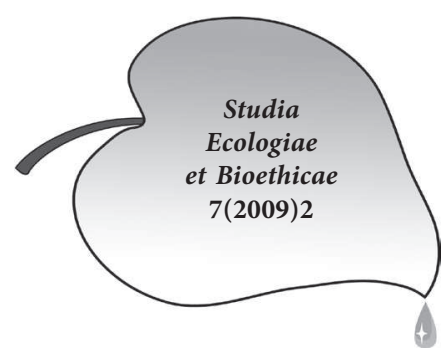

\title{
Zwierzęta domowe w nauczaniu Jezusa
}

Pan Jezus ukazany na kartach ewangelii wędruje „przez miasta i wsie, nauczając i głosząc Ewangelię o królestwie Bożym” (Łk 8,1). Dokonuje przy tym spektakularnych cudów, którymi zadziwia słuchające i obserwujące Go tłumy, „tak że byli zdumieni i pytali: Skąd u Niego ta mądrość i cuda?” (Mt 13,54). Główną część Jego działalności stanowiło jednak nauczanie (por. np. Mt 5,2; 9,35;21,23; Mk 1,21; 2,13; $6,6 ; 10,1 ; Ł k 4,15.31 ; 5,3 ; 6,6 ; \mathrm{J} 7,14 ; 8,2)$. Słuchacze byli poruszeni Jego nauką do tego stopnia, że nawet Go wysławiali (por. Łk 4,15: „On zaś nauczał w ich synagogach, wysławiany przez wszystkich"; por. też Mt 9,33), a strażnicy, którzy mieli Go pochwycić, lecz nie uczynili tego, powiedzą do arcykapłanów i faryzeuszy: „nigdy jeszcze nikt tak nie przemawiał jak ten człowiek" (J 7,46).

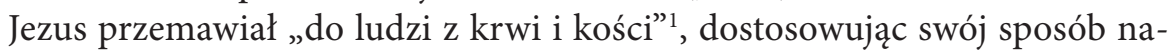
uczania do poziomu słuchaczy. Dlatego też wielokrotnie stosował metafory, parabole, symbole i wieloznaczne terminy oraz wykorzystywał różne „pola obrazów"2 z dziedziny ekologii, aby być zrozumiałym dla swoich odbiorców, aby ich przekonać i aby wywrzeć na nich wrażenie ${ }^{3}$. Często nawiązywał Jezus do świata zwierząt, do rzeczywistości znanej słuchaczom. Przywoływał w swoim nauczaniu zwierzęta domowe: psy, świnie, owce, kozły, woły, osły i wielbłądy nie tylko

R. BARTNICKI, Ewangelie synoptyczne. Geneza i interpretacja, Warszawa ${ }^{2} 1996,133$.

2 Pod pojęciem „pola obrazu“ należy rozumieć zgrupowania metafor, które występują często w grupach i w łączności z innymi metaforami. Tak C.G. Müller, Gottes Pflanzung - Gottes Bau - Gottes Tempel. Die metaphorische Dimension paulinischer Gemeindetheologie in 1Kor 3,517 (FuSt 5), Frankfurt/M. 1995, 30. H. WeInRICH, Sprache in Texten, Stuttgart 1976, 283 uważa, że tak jak pojedynczy wyraz w języku nie ma oddzielnej egzystencji, tak też pojedyncza metafora należy do pola obrazu; ona jest „miejscem w polu obrazu”. D. PEIL, Untersuchungen zur Staats- und Herrschaftsmetaphorik in literarischen Zeugnissen von der Antike bis zur Gegenwart, München 1983, 24 jako „pole obrazu“ rozumie strukturę, która składa się z różnych elementów obrazu i istniejących między nimi relacji. Zarówno elementy, jak i relacje mogą zmieniać się ze względu na ich liczbę i zabarwienie, tak że możliwe są różne warianty i odcienie obrazów. Por. też R. Zimmermann, Die Gleichnisse Jesu, w: Tenże (red.), Kompendium der Gleichnisse Jesu, Gütersloh 2007, 3-46, 39-41.

3 Por. A.J. NAJDA, Nowe perspektywy w badaniach nad przypowieściami Jezusa, Zeszyty naukowe Stowarzyszenia Biblistów Polskich 6(2009), 291-310, 295. 
w znaczeniu realnym, lecz przede wszystkim w znaczeniu przenośnym. Czynił to zwłaszcza wtedy, gdy pragnął wyrazić trudne do wyrażenia słowami prawdy o królestwie Bożym.

\section{Pies}

W nauczaniu o królestwie Bożym Jezus kilka razy posługuje się obrazem psa, który jest najstarszym, udomowionym zwierzęciem na świecie i najstarszym towarzyszem człowieka. W Mezopotamii kojarzono go zarówno ze zdrowiem, jak i z chorobą. Był bowiem atrybutem Guli - bogini zdrowia, jak i wyobrażeniem Lamasztu - demona chorób i śmierci, którego przedstawiały gliniane figurki psa, strzegące wejścia do zaświatów. W Egipcie podobizna psa wyobrażała władcę zaświatów, a hinduskiego niszczyciela, boga Sziwę, określano mianem „Pana psów”4.

W Starym Testamencie pies, jako zwierzę nieczyste, ujmowany jest zazwyczaj w kategoriach negatywnych. Symbolizuje to, co zwykłe, pospolite i budzące odrazę (por. Prz 26,11: „Jak pies do wymiotów powraca, tak głupi powtarza szaleństwa"). Żywi się odpadami, a jego zachowania są często dla człowieka niebezpieczne. Biblia wspomina o psach jako stróżach ludzi i ich dobytku oraz jako towarzyszach pasterzy. Strzegły one namiotów lub domów i szczekały na obcych, żywiły się rzucanymi im odpadkami, a ich warczenie można było usłyszeć w miastach (por. Ps 59,7; Hi 30,1). Nazwanie kogoś psem było obelgą i wyrażało pogardę wobec człowieka (1 Sm 17,43). W Nowym Testamencie Paweł ostrzega pochodzących z pogaństwa wierzących, aby się strzegli się psów, którymi są chrześcijanie skłaniający się ku judaizmowi (Flp 3,2)5. W Apokalipsie zaś psy wymienia się obok guślarzy, rozpustników, zabójców, bałwochwalców oraz kochających i żyjących kłamstwem, którzy pozostają „na zewnątrz” (Ap 22,15), to znaczy nie odziedziczą królestwa Bożego ${ }^{6}$. W późniejszych wiekach zanikł negatywny obraz psa. Pies stał się symbolem wierności, czujności, i cnoty małżeńskiej ${ }^{7}$.

Jezus mówi o psach w znaczeniu realnym i przenośnym. W zapisanej tylko przez ewangelistę Łukasza przypowieści o bogaczu i leżącym u bramy jego pałacu Łazarzu (16,19-31) scharakteryzuje Jezus Łazarza słowami: „Pragnął on nasycić się odpadkami ze stołu bogacza; nadto i psy przychodziły i lizały jego wrzody” $(16,21)$. Jezus ma tu na myśli rzeczywiste psy $^{8}$.

Inaczej jest w opowiadaniu o głębokiej wierze kobiety, której córka była opętana przez złego ducha (Mk 7,24-30; Mt 15,21-28). Marek relacjonuje: „Przyszła,

\footnotetext{
Por. M. LuRKer, Słownik obrazów symboli biblijnych, Poznań 1989, 178.

Por. J. GnIlKa, Der Philipperbrief (HThK X/3), Freiburg im Breisgau ${ }^{4} 1987,185 n$.

Por. H. Giesen, Die Offenbarung des Johannes (RNT), Regensburg 1997, 488-490.

Por. B. Szczepanowicz - A. Mrozek, Atlas zwierząt biblijnych. Miejsce w Biblii i symbolika, Kraków 2007, 36n.

8 Por. E. Schweizer, Das Evangelium nach Lukas (NTD $3^{20}$ ), Göttingen ${ }^{3} 1993,172$ n.
} 
upadła Mu do nóg, a była to poganka, Syrofenicjanka rodem, i prosiła Go, żeby złego ducha wyrzucił z jej córki” (7,25b-26). W odpowiedzi usłyszała: „Pozwól wpierw nasycić się dzieciom; bo niedobrze jest zabrać chleb dzieciom, a rzucić psom" $(7,27)$. Jezus nie odrzuca prośby owej kobiety. Wykorzystując obraz z codziennego życia, wyjaśnia jej, że przyszedł, aby najpierw „nasycić dzieci”, to znaczy naród Izraela. To im przysługuje pierwszeństwo w otrzymywaniu Jego zbawczej mocy. Psy określają tutaj pogan i nie są wyrazem jakiejś pogardy. Potwierdza to reakcja Syrofenicjanki, która głęboko wierzy, że Chrystus wysłucha jej prośby. Nawiązując do użytej przez Jezusa metaforyki, odpowiada: „Tak, Panie, lecz i szczenięta pod stołem jadają z okruszyn dzieci” $(7,28)$. „Przez wzgląd na te słowa" $(7,29)$ jej córka została uzdrowiona 9 .

O psach w znaczeniu przenośnym wspomina Chrystus także w znajdującym się jedynie u Mateusza „Kazaniu na górze” (Mt 5-7). Wzywając do powściągliwości w wydawaniu sądów o innych ludziach $(7,1-2)$ i przestrzegając przed obłudą (7,3-5), kończy Jezus swoją wypowiedź nieoczekiwaną przenośnią: „Nie dawajcie psom tego, co święte, i nie rzucajcie swych pereł przed świnie, by ich nie podeptały nogami, i obróciwszy się, was nie poszarpały" $(7,6)$. Wymienione zwierzęta uchodziły wśród Izraelitów za nieczyste i należało strzec się kontaktu z nimi. Słowa Chrystusa to swoiste napomnienie, aby Jego naukę - nazwaną mianem „pereł” - głosić z należytą roztropnością i wielkim szacunkiem ${ }^{10}$.

\section{2. Świnia}

Wspomniane w Kazaniu na górze (Mt 7,6) świnie tylko w tym miejscu występują w znaczeniu przenośnym. Słów Jezusa nie należy jednak rozumieć jako zakazu głoszenia dobrej nowiny o zbawieniu poganom, których świnie miałyby symbolizować ze względu na ich nieprzyjmowanie czy wręcz pogardę dla żydowskiego prawa. Chodzi tu raczej o słuchaczy, którzy nie są gotowi na przyjęcie ewangelii, ponieważ rzeczy najcenniejsze, określane mianem pereł, „traktują jako pozbawione wartości i godne pogardy"11.

Dla starożytnych ludów pogańskich świnia była symbolem płodności i z tej racji stanowiła ofiarę dla bóstw. Zwyczaj ten znano w Egipcie, gdzie w dniu święta księżyca Ozyrysowi składano w ofierze właśnie świnię. Wolno było też wtedy spożywać mięso wieprzowe ${ }^{12}$. Spożywanie mięsa świńskiego zakazane było nie tylko Żydom, lecz także Hindusom, Arabom i Egipcjanom. Liczne hodowle wie-

\footnotetext{
9 Por. J. Gnilka, Das Evangelium nach Markus. 1. Teilband Mk 1-8,26 (EKK II/1), Zürich Einsiedeln - Köln - Neukirchen-Vluyn 1978, 289-295.

10 Por. U. Luz, Das Evangelium nach Matthäus. 1. Teilband Mk 1-7 (EKK I/1), Zürich - Einsiedeln - Köln - Neukirchen-Vluyn 1985, 381n.

11 E. Ryken - J. Wilhoit - T. Longman III, Słownik Symboliki Biblijnej, Warszawa 2003, 1001.

12 M. LuRKer, dz. cyt. 240.
} 
przów u Egipcjan podyktowane były względami rolniczymi. Po ustąpieniu wód Nilu po corocznym wylewie, wypędzano na rozmiękłe tereny świnie, aby ryły i tratowały ziemię i w ten sposób - zastępując niejako orkę - przygotowały ją pod zasiew $^{13}$. Dla niektórych plemion syryjskich świnia była zwierzęciem świętym, powiązanym z Asztarte ${ }^{14}$, boginią płodności.

W Starym Testamencie świnia należy do zwierząt nieczystych (Kpł 11,7). Zakazane było spożywanie mięsa wieprzowego, a nawet dotykanie zdechłej świni (Pwt 14,8). Ludzie jedzący mięso świń, to bezbożnicy i buntownicy (por. Iz 65,4). Otaczający świnie brud symbolizuje wewnętrzne zbrukanie człowieka. Pozbawiona zaś rozsądku kobieta to „złota obrączka w ryju świni” (Prz 11,22). Natomiast narody pogańskie, które niszczą Izraela - „winnicę Pańską” (Iz 5) - to dzikie świnie (Ps 79,14). Także w późniejszych czasach świnia symbolizowała nieczystość, brud, niegodność i głupotę człowieka ${ }^{15}$.

Świnie pojawiają się w nauczaniu Jezusa również w znaczeniu realnym, a dokładniej w znajdującej się tylko u Łukasza $(15,11-32)$ przypowieści o synu marnotrawnym ${ }^{16}$. Młodszy syn po zabraniu od ojca przysługującej mu części mająt$\mathrm{ku}$, wyrusza w dalekie kraje, gdzie żyje rozrzutnie i roztrwania majątek $(15,12 \mathrm{n})$. Nie mając środków do życia podejmuje pracę przy pasieniu świń. Dla Żyda było to najbardziej upokarzające zajęcie i oznaczało upadek na samo dno oraz bezkresne poniżenie człowieka (Łk 15,15). Wtedy ów młodszy syn zrozumiał swoje położenie. Opamiętał się i postanowił wrócić do Ojca (Łk 15,16-18) $)^{17}$.

\section{Owca}

Wielokrotnie mówi Jezus w ewangeliach o owcach, które wraz z baranami i jagniętami są najczęściej wymienianymi zwierzętami na kartach Pisma świętego. Wynika to nie tylko z ważnej roli owiec najpierw w nomadycznym, a później w rolniczym społeczeństwie Hebrajczyków, lecz przede wszystkim ze znaczenia owiec i baranków jako ofiar składanych Bogu w Starym Testamencie. Ofiarę z baranka składano przy konsekracji kapłanów (Wj 29; Kpł 8,18-25) i w takich ofiarach, jak: zadośćuczynienie za popełniony nieświadomie grzech (Kpł 5,15.18), oczyszczenie po połogu (Kpł 12), oczyszczenie trędowatego (Kpł 14,10.12-13),

13 Por. D. Forstner, Świat symboliki chrześcijańskiej, Warszawa 1990, 303.

14 Dokładnie na ten temat pisze C. Bonnet, Astarté. Dossier documentaire et perspectives historiques, Roma 1996.

15 Por. B. Szczepanowicz - A. Mrozek, dz. cyt. 83n.

16 Pomijamy tu opis uzdrowienia opętanego w kraju Gerazeńczyków (Mk 5,1-20 i par.), ponieważ nie chodzi w nim o nauczanie Jezusa, lecz o cud. Na prośbę wypędzanych złych duchów Jezus posyła ich w stado świń, które ruszają pędem do Jeziora Galilejskiego i toną w jego wodach.

17 Por. E. Schweizer, dz. cyt. 163-167; K. Romaniuk - A. Jankowski - L. Stachowiak, Komentarz praktyczny do Nowego Testamentu I, Poznań - Kraków ${ }^{2} 1999$, 362-364. 
ofiary biesiadne (Kpł 9,18-22) i ofiara całopalna składana w Dniu Przebłagania (Kpł 16,3). Zabity baranek ofiarowany Jahwe symbolizował człowieka, który oddaje Bogu to co ma najcenniejszego - własne życie. Ze względu na bierność wobec zadawanego cierpienia owca stała się symbolem prześladowań (Ps 44,23: „Lecz to przez wzgląd na Ciebie ciągle nas mordują, mają nas za owce na rzeź przeznaczone"). Ofiarę z baranka składali Izraelici w noc, przed wyjściem z Egiptu (Wj 12,3-7). W Nowym Testamencie barankiem ofiarnym jest Chrystus (1 Kor 5,7; 1 P 1,19; Ap 5,12; 7,14.17; 12,11; 17,14). Jan Chrzciciel powie o Jezusie: „Oto Baranek Boży, który gładzi grzech świata" (J 1,29; por. 1, 36) ${ }^{18}$.

Już w Starym Testamencie owce to metafory ludzi, którzy są bezradni, narażeni na niebezpieczeństwo, błądzą i dlatego potrzebują pasterza. Tym pasterzem jest Jahwe, który wprowadza owce, to jest członków narodu wybranego, do owczarni i sprawdza, czy wszystkie wróciły (Ez 20,37). Jahwe odszuka zagubioną owcę, zabłąkaną sprowadzi z powrotem, skaleczoną opatrzy, chorą umocni, a tłustą i mocną będzie ochraniał (Ez 34,16; por. Iz 40,11). W Ps 23, który rozpoczynają słowa wychwalające Boga: „Pan jest moim pasterzem, nie brak mi niczego”, znajduje się potwierdzenie tych Boskich, pełnych łaski działań ${ }^{19}$.

Jezus w swoim nauczaniu często nawiązuje do znanych Jego słuchaczom „pól obrazów” pasterza i owiec ${ }^{20}$. Ma na myśli rzeczywiste owce w przypowieści o zabłąkanej owcy (Łk 15,1-7; por. Mt 18,12-14). Stawiając pytanie: „Któż z was, gdy ma sto owiec, a zgubi jedną z nich, nie zostawia dziewięćdziesięciu dziewięciu na pustyni i nie idzie za zgubioną, aż ją znajdzie?" $(15,4)$ zakłada pozytywną odpowiedź, to znaczy, że tak czyni każdy człowiek. Radość zaś ze znalezionej owcy, której wyrazem jest uczta z przyjaciółmi i sąsiadami, obrazuje radość, jaka powstaje w niebie „z jednego grzesznika, który się nawraca” $(15,10)^{21}$. Podobnie zapyta w synagodze, w której w dniu szabatu spotyka człowieka mającego uschłą rękę (Mt 12,9-14). Odpowiadając zgromadzonym na pytanie, czy można uzdrawiać w szabat, Jezus odwołuje się do pospolitej owcy: „Kto z was jeśli ma jedną owcę, i jeżeli mu ta w dół wpadnie w szabat, nie chwyci i nie wyciągnie jej?" $(12,11)$. Wyjaśnia, że tak postępuje każdy człowiek. Przypomina przy tym naznaczony przez Boga porządek stworzenia, stwierdzając kategorycznie: „O ileż ważniejszy jest człowiek niż owca!” $(12,12)^{22}$.

18 Por. M. Lurker, dz. cyt. 21-24; E. Ryken - J. Wilhoit - T. Longman III, dz. cyt. 31.

19 Por. B. Willmes, Die sogenannte Hirtenallegorie Ez 34. Studien zum Bild des Hirten im Alten Testament (BET 19), Frankfurt am Main - Bern - New York - Nancy 1984, 311-342; B. Szczepanowicz - A. Mrozek, dz. cyt. $67 \mathrm{n}$.

20 Ewangelista Mateusz odnotowuje, że Jezus „widząc tłumy ludzi, litował się nad nimi, bo byli znękani i porzuceni, jak owce nie mające pasterza” (9,36; por. Mk 6,34).

21 Por. K. Romaniuk - A. Jankowski - L. Stachowiak, dz. cyt. 360n.

22 Por. J. Gnilka, Das Matthäusevangelium. Erster Teil. Kommentar zu Kapitel 1,1 - 13,58 (HThK. NT I/1), Freiburg - Basel - Wien ${ }^{3} 1993,447-449$. 
O wiele częściej mówi Jezus o owcach w znaczeniu metaforycznym. Owcami są najpierw - tak jak w Starym Testamencie - członkowie narodu wybranego, i to do nich kieruje najpierw Jezus swoją ofertę zbawczą. Oświadczy to wprost kobiecie kananejskiej (Mt 15,21-28), która prosi Go o uzdrowienie nękanej przez złego ducha swojej córeczki, stwierdzając: „Jestem posłany tylko do owiec, które poginęly z domu Izraela" $(15,24)^{23}$. Również do wybranych przez Siebie dwunastu apostołów (Mt 10,1-4), gdy posyła ich z misją głoszenia królestwa niebieskiego, uzdrawiania, wskrzeszania umarłych, oczyszczania trędowatych i wypędzania złych duchów (10,7-8), powie: „Idźcie raczej do owiec, które poginęły z domu Izraela" $(10,6)$.

Sami apostołowie - u Mateusza owych dwunastu, u Łukasza to „jeszcze innych siedemdziesięciu dwu" $(10,1)^{24}$ - posłani są ,jak owce między wilki” (Mt 10,16; Łk 10,3). Sformułowanie to wyraża niebezpieczeństwo, jakie grozi uczniom, wysłanym przez Jezusa na głoszenie królestwa Bożego. Pokazuje też, kim są misjonarze w porównaniu do ich przeciwników. Są tylko owcami, które pośród drapieżnych wilków nie mają wielkich szans na przeżycie. Posługując się obrazem owcy w odniesieniu do swoich uczniów, Jezus opisuje ich aktualną sytuację w Izraelu. $Z$ ich posługą wiąże się niezrozumienie ze strony słuchaczy, odrzucenie, prześladowanie, a nawet przemoc. Uczniowie Jezusa wobec prześladowców mają się zachowywać jak owce, to znaczy „nie odpłacając zemstą za doznane zło"25. Potwierdzają to wcześniejsze wskazania z Kazania na górze (5,38$48)$ i zalecenie, aby nie brali ze sobą laski obronnej $(10,10)$.

Swoich apostołów określa Jezus mianem owiec również zapowiadając swoją mękę i śmierć krzyżową oraz zachowanie uczniów wobec tych wydarzeń. Po spożyciu Ostatniej Wieczerzy w Wieczerniku, podczas której Jezus ustanowił sakrament Eucharystii i kapłaństwa (Mk 14,12-25 i par.), w drodze na Górę Oliwną Jezus powie: „Wszyscy zwątpicie we Mnie. Jest bowiem napisane: «Uderzę Pasterza, a rozproszą się owce»" (Mk 14,27; Mt 26,31). Posługując się cytatem z Za 13,7, Jezus zapowiada ich upadek, który będzie polegał na ich rozproszeniu - „owce rozbiegną się"26.

W nauczaniu Jezusa owcami są przede wszystkim wierzący w Niego ludzie, którzy słuchają Jego słów i chodzą za Nim. Wielokrotnie jest o tym mowa w rozdziale dziesiątym Ewangelii wg św. Jana., w mowie pasterskiej Jezusa (10,1-21) ${ }^{27}$.

23 Por. U. Luz, Das Evangelium nach Matthäus. 2. Teilband Mk 8-17 (EKK I/2), Zürich Braunschweig - Neukirchen-Vluyn 1990, 430-437.

24 Por. E. Schweizer, dz. cyt. 113n. H. LangKammer, Ewangelia według św. Łukasza. Tłumaczenie, wstep i komentarz, Lublin 2005, 275n.

25 Paciorek 429.

26 Por. A. Paciorek, Ewangelia według świetego Mateusza. Rozdziały 14-28. Wstęp, przekład $z$ oryginału, komentarz (NKB.NT I/2), Częstochowa 2008, 567.

27 Dokładnie na ten temat B. Kowalski, Die Hirtenrede im Kontext des Johannesevangeliums (Joh 10,1-18) (SBB 31), Stuttgart 1996. 
Nawiązuje On najpierw do dobrze znanych jego słuchaczom ówczesnych warunków przetrzymywania owiec we wspólnych, otoczonych murem zagrodach, w których wielu posiadaczy mniejszych trzód trzymało swoje owce. Nad trzodami czuwał zatrudniony przez posiadaczy trzód odźwierny. Gdy przychodził pasterz, odźwierny otwierał mu bramę, by ten wyprowadził swoje owce, wołając je po imieniu, co było powszechnym zwyczajem w basenie Morza Śródziemnego (por. J 10,2n $)^{28}$. Owce „postępują za nim, ponieważ głos jego znają” $(10,4)$. Jezus stawia tu siebie w roli pasterza, który wzywa swoje owce po imieniu. Te znają Jego głos i idą za Nim. Używając tej metafory zaznacza, że wierzący w Niego powinni słuchać Jego głosu, to jest otworzyć się na Jego naukę i „postępować za Nim", to znaczy nie tylko żyć wedle wskazań tej nauki, lecz także iść za Jezusem. Pójście za Nim to naśladowanie Go w swoim życiu, a zwłaszcza Jego pokory, dobroci, oddania dla innych i gotowości do podjęcia codziennego krzyża czyli trudności, przeciwności i cierpienia.

Słuchacze nie zrozumieli jednak znaczenia słów Jezusa. Dlatego powiedział powtórnie, w uroczystym tonie: „Zaprawdę, zaprawdę powiadam wam: Ja jestem bramą owiec” (J 10,7). Jezus objawiając się jako „brama owiec” $(10,7)^{29}$, wskazuje na swoje prawo wejścia do owczarni i bycia jej pasterzem. Wchodząc jedynie tą bramą, owce osiągną szczęście, ponieważ tylko On jest dawcą i pośrednikiem zbawienia $^{30}$. Jezus mówi tu (por. 10,9: „Ja jestem bramą") o swoim zadaniu, jakie spełnia On jako brama dla wierzących w Niego ${ }^{31}$. Jezus jest bramą, to znaczy jedynym miejscem, przez które owce przechodzą na pastwisko, czyli osiągają zbawienie $^{32}$. On przyszedł bowiem na świat po to, aby Jego owce „miały życie i miały je w obfitości" $(10,10)$.

W dalszej części swojej mowy pasterskiej $(J$ 10,11-18) Jezus dwa razy $(10,11.14)$ powie o sobie: „Ja jestem dobrym pasterzem”. Przedstawiając dalej zadania dobrego pasterza, podkreśla, że dobry pasterz „daje życie swoje za owce” (10,11). Owce są jego własnością, on nie opuszcza ich i nie ucieka na widok nadchodzącego wilka, tak jak czyni to najemnik (10,12-13). To oddanie życia jest dobrowolnym czynem Jezusa, który w ten sposób spełnia zbawczą wolę Ojca. Jezus ma moc oddać życie

28 Por. M. Theobald, Herrenworte im Johannesevangelium (HBS 34), Freiburg im Breisgau - Basel - Wien - Barcelona - Rom - New York 2002, 362.

29 Słowa „Ja jestem” są starotestamentalną formułą objawieniową Boga. Jezus przedstawia się tu jako Bóg. Por. A.J. NAJDA, Ekologiczne samookreślenia Jezusa w Ewangelii wg św. Jana, w: Studia Ecologiae et Bioethicae 6(2008), 93-104, 98-100.

30 R. SCHnackenburg, Das Johannesevangelium. Zweiter Teil: Kommentar zu Kapitel 5- 12 (HThK IV/2), Freiburg - Basel - Wien ${ }^{5} 1990$, 363-366.

31 Brama jako symbol Zbawcy może posiadać także znaczenie mesjańskie z Ps 118,19-20: „Otwórzcie mi bramy sprawiedliwości: chcę wejść i złożyć dzięki Panu. Oto jest brama Pana, przez nią wejdą sprawiedliwi“, por. A. PACIOREK, Ewangelia według św. Jana 134.

32 Por. U. Wilckens, Das Evangelium nach Johannes (NTD 4 ${ }^{18}$ ), Göttingen ${ }^{2} 2000,165$. 
i ma moc znów je odzyskać $(10,18)$. Mówiąc o oddaniu życia za owce, ma myśli rzeczywiste i dobrowolne oddanie życia, którego - jako wyraz ofiarnej miłości pasterza $^{33}$ - dokona na krzyżu. Jezus wyzna również, że zna swoje owce, a jego owce Go znają, podobnie jak zna Go Ojciec, a On zna Ojca. Słowami tymi określa swoją relację z owcami, naznaczoną wzajemną znajomością, zaufaniem i miłością. Chodzi bowiem o więź osobową, poznanie prowadzące do głębokiej wspólnoty miłości, jaką Bóg obdarza swój lud i każdego człowieka ${ }^{34}$. Zaś wyrazem tej nieskończonej miłości jest Jezusowa zapowiedź oddania życia za owce $(10,15)$. Inne owce, o których wspomina Jezus, to ludy pogańskie, które także pragnie przyprowadzić. Chce zgromadzić owce nie tylko z Izraela, lecz również ze wszystkich narodów, aby nastała „jedna owczarnia, jeden pasterz" $(10,16)^{35}$.

Mianem owiec nazywa Jezus wszystkich wierzących w Niego, kiedy po swoim Zmartwychwstaniu przekazuje Piotrowi urząd pasterski w Kościele (J 21,15-19). Nawiązując do trzykrotnego zaparcia się Apostoła, Jezus trzy razy stawia mu pytanie: „Szymonie, synu Jana, czy miłujesz Mnie więcej, aniżeli ci?” (21,15.16.17). Trzykrotnie Szymon zapewni o swojej miłości do Jezusa: „Tak, Panie, Ty wiesz, że Cię kocham”36. W odpowiedzi usłyszy: „Paś baranki moje” $(21,15)$, a po drugim i trzecim pytaniu: „Paś owce moje” $(21,16.17)$. Jezus powierza Piotrowi swoją trzodę, a określenia owce i baranki to wierzący w Chrystusa.

W opisie Sądu Ostatecznego owce symbolizują wreszcie dobrych ludzi, którzy otrzymają wieczną nagrodę (Mt 25,31-46). Gdy przy końcu świata Syn Człowieczy przyjdzie w chwale, zasiądzie na swoim tronie i będzie sądził wszystkie narody, wtedy oddzieli ludzi, tak jak pasterz rozdziela owce od kozłów. Owce postawi po swojej prawej stronie, a kozły po lewej $(25,33)$. Do tych znajdujących się po prawej stronie - nienazwanych już owcami - Sędzia, który jest Królem, powie: „Pójdźcie, błogosławieni Ojca mojego, weźcie w posiadanie królestwo, przygotowane wam od założenia świata!” $(25,34)$. Uzasadniając swój wyrok, wymieni dokonane przez nich uczynki miłosierdzia, które wykonali dla Niego: dali Mu jeść i pić, gdy był głodny i spragniony, przyjęli Go, gdy był przybyszem, przyodziali Go, gdy był nagi, odwiedzili Go podczas choroby i przyszli do Niego, gdy przebywał w więzieniu $(25,35 \mathrm{n})$. Owi sprawiedliwi zdziwili się na te słowa, ponieważ nie wiedzieli, kiedy uczynili to wszystko dla Niego. Król oświadczy im wtedy: „Zaprawdę, powiadam wam: Wszystko, co uczyniliście jednemu z tych braci moich najmniejszych, Mnieście uczynili” $(25,40)^{37}$.

33 Por. R. Schnackenburg, dz. cyt. 371n.

34 Por. U. Wilckens, dz. cyt. 166.

35 Por. A. PACIOREK, Ewangelia według św. Jana. Tłumaczenie, wstęp i komentarz, Lublin 2000, 135.

36 Trzecia odpowiedź Piotra jest trochę zmodyfikowana, ze względu na jego smutek z powodu trzykrotnego pytania. Brzmi ona: „Panie, Ty wszystko wiesz, Ty wiesz, że Cie kocham” (J 21,17).

37 W sprawie rozumienia tekstu por. Ekskurs 3 Kierunki interpretacji perykopy o sadzie ostatecznym (Mt 25,31-46) w: A. PACIOREK, Ewangelia wedtug świętego Mateusza II 520-527. 


\section{Kozioł}

Kozioł pojawia się w nauczaniu Jezusa tylko jeden raz, we wspomnianym opisie Sądu Ostatecznego (Mt 25,32n). Na starożytnym Wschodzie kozioł poświęcony był babilońskiemu bogu Mardukowi, mezopotamskiemu Tammuzowi, sumeryjskiemu Ninurcie, babilońsko-asyryjskiej Isztar, bogini miłości i płodności natury. Niewolnicom posługującym w świątyni Isztar czy w świątyni Afrodyty w Koryncie płacono w naturze koźlęciem. Jako zwierzę płodne i ogniste stał się kozioł „wyobrażeniem rozpusty i lubieżności” ${ }^{38}$. Kozły składano w ofierze również podczas świąt poświęconych Dionizosowi, bogu wina i płodnych sił natury ${ }^{39}$.

W Starym Testamencie kozły obok byków, baranów i gołębi składano Jahwe jako ofiary całopalne w intencji przebłagania i oddania czci. W dorocznym Dniu Przebłagania kapłan zabija najpierw kozła jako ofiarę przebłagalna za lud (Kpł 16,15-19), a potem każe przyprowadzić żywego kozła, kładzie ręce na jego głowę, „wyzna nad nim wszystkie winy Izraelitów, wszystkie ich przestępstwa dotyczące wszelkich ich grzechów, włoży je na głowę kozła i każe człowiekowi do tego przeznaczonemu wypędzić go na pustynię" (Kpł 16,21n). Kojarzony z grzechem kozioł ofiarny symbolizuje człowieka, którego obciążono cudzymi winami, oskarżono i potępiono za nie ${ }^{40}$.

W Mateuszowym opisie Sądu Ostatecznego (25,31-46) Król stawia kozły po swojej lewej stronie. Powie do nich: „Idźcie precz ode Mnie, przeklęci, w ogień wieczny, przygotowany diabłu i jego aniołom!” $(25,41)$. Owymi kozłami są ludzie, którzy nie pełnili uczynków miłosierdzia i dlatego „pójdą... na wieczna karę" $(25,46)$. Król zarzuca im, że nie dali mu jeść ani pić, nie przyjęli Go, nie przyodziali ani nie odwiedzili Go. Oskarżeni, podobnie jak symbolizowani przez owce sprawiedliwi (25,37-39), zdziwili się, ponieważ nie wiedzieli, kiedy nie usłużyli będącemu w potrzebie Królowi. Ten odpowie im: „Zaprawdę, powiadam wam: Wszystko, czego nie uczyniliście jednemu z tych najmniejszych, tegoście i Mnie nie uczynili” $(25,45)^{41}$.

\section{Wół}

Głosząc królestwo Boże, Jezus wspomina także o wołach, które symbolizowały nie tylko ofiary, lecz także uprawę roli i rozwój cywilizacji. Wraz z osłami, wielbłądami, owcami i kozami stanowiły one główne bogactwo starożytnych ludów pasterskich. W Starym Testamencie dwanaście wołów podtrzymywało „brą-

\footnotetext{
38 W. Kopaliński, Słownik symboli, Warszawa 2006, 164.

39 Tamże.

40 Por. B. Szczepanowicz - A. MrozeK, dz. cyt. 81n.

${ }^{41}$ Por. J. Gnilka, Das Matthäusevangelium. Zweiter Teil. Kommentar zu Kapitel 14,1 - 28,20 (HThK.NT I/2), Freiburg - Basel - Wien ${ }^{2} 1992,366-379$.
} 
zowe morze" w świątyni Salomona (1 Krl 7,25). Z morza tego czerpano wodę do ablucji kapłanów, co podkreślało wartość byków jako najbardziej cennych zwierząt ofiarnych. Wół wyobraża również moc Bożą w wizji czterech istot żyjących u proroka Ezechiela $(1,5.10)$ i później w Apokalipsie św. Jana Apostoła $(4,7)$. Związana $\mathrm{z}$ wołem idea ofiary spowodowała, że stał się on symbolem ewangelisty Łukasza $^{42}$.

Jezus mówi o wołach jedynie w znaczeniu realnym. W przypowieści o uczcie królewskiej (Mt 22,1-14) przygotowane do spożycia woły i tuczne zwierzęta symbolizują obfitość i wystawność owej uczty. W Łukaszowej wersji tej przypowieści $(14,15-24)$ jeden z zaproszonych odmawia przyjęcia zaproszenia na ucztę, ponieważ kupił pięć par wołów i chce je wypróbować $(14,19)$. Woły są dla niego ważniejsze od pójścia na ucztę, to znaczy od królestwa Bożego ${ }^{43}$. Do obrazu wołu odwołuje się Jezus także po uzdrowieniu w szabat niewiasty, która od osiemnastu lat chorowała, nie mogła się wyprostować (Łk 13,10-17). Odpowiadając na wyrażone oburzenie przełożonego synagogi z powodu nieprzestrzegania szabatu, Jezus zapyta: „Obłudnicy, czyż każdy z was nie odwiązuje w szabat wołu lub osła od żłobu i nie prowadzi, by go napoićc?" $(13,15)$. Usłyszawszy te słowa, wszyscy się zawstydzili $(13,16)^{44}$. W podobnym tonie zwraca się Jezus do faryzeuszy i uczonych w Prawie po uzdrowieniu w szabat człowieka chorego na wodną puchlinę: „Któż z was, jeśli jego syn albo wół wpadnie do studni, nie wyciągnie go zaraz, nawet w dzień szabatu?" (Łk 14,5) ${ }^{45}$.

\section{Osioł}

Osioł, choć kojarzony z Jezusem i jego podróżowaniem, pojawia się w nauczaniu Chrystusa tylko sporadycznie. Egipcjanie widzieli w nim zwierzę demoniczne, które pozostawało pod panowaniem złego Seta. Hindusi postrzegali w ośle zwierzę lubieżne i kojarzyli go z nieczystością. Dla Syryjczyków był zwierzęciem świętym, ponieważ jeździła na nim bogini Atirat. W Grecji zaś dosiadał go bóg Dionizos podczas świątecznych orszaków bachicznych. Także w Starym Testamencie symbolizował osioł rozpustę z powodu swoich dzikich podniet (Ez 23,20). Szczęką oślą Samson zabił tysiąc ludzi (Sdz 15,15). Osioł służył też jako wierzchowiec. Był też znakiem zamożności (por. Sdz 5,10; 12,14) i symbolem Mesjasza (Za 9,9: „Raduj się wielce, Córo Syjonu, wołaj radośnie, Córo Jeruzalem! Oto Król twój idzie do ciebie, sprawiedliwy i zwycięski. Pokorny jedzie na osiołku, na oślątku, źrebięciu oślicy”; por. Rdz 49,11) ${ }^{46}$.

\footnotetext{
42 Por. D. Forstner, dz. cyt. 253.

43 Por. E. Schweizer, dz. cyt. $157 \mathrm{n}$.

44 Por. K. Romaniuk - A. Jankowski - L. Stachowiak, dz. cyt. 350n.

45 Tamże 354n.

46 Por. M. Lurker, dz. cyt. 162n.
} 
Jezus odwołuje się do zwyczaju odwiązywania osła w dzień szabatu, odpowiadając oburzonemu przełożonemu synagogi (Łk 13,5). Wjeżdżając zaś w niedzielę palmową na młodym osiołku, którego jeszcze nikt nie dosiadał, do Jerozolimy (J 12,14n), realizuje zapowiedzi mesjańskie Starego Testamentu ${ }^{47}$.

\section{Wielbłąd}

W nauczaniu o królestwie Bożym Jezus mówi też o wielbłądach. Znane powszechnie na starożytnym Wschodzie wielbłądy jednogarbne, zwane dromaderami, mogły obyć się bez wody przez siedemnaście dni. Posiadały wiele cech, pozwalających im na długi marsz przez pustynię i dlatego stanowiły niezastąpione zwierzęta wierzchowe i juczne dla ludzi mieszkających na terenach pustynnych $^{48}$. Dromadery wielokrotnie wspominają teksty biblijne, przede wszystkim opowiadania o patriarchach Izraela. Wielbłądy to zwierzęta pod wierzch (Rdz 31,17; 24,10n.61.64), są częścią trzód ( $\operatorname{Rdz} 30,43 ; 32,8)$, zapłat i danin (Rdz 12,16; $32,16)$.

Jezus mówi o wielbłądzie, przestrzegając swoich uczniów przed niebezpieczeństwem bogactw (Mk 10,23-27; por. Mt 19,23-26; Łk 18,24-27). Ludzie opływający w dostatki mają trudność z dostaniem się do królestwa Bożego. Skalę tej trudności obrazuje Jezus stwierdzeniem: „Łatwiej jest wielbłądowi przejść przez ucho igielne, niż bogatemu wejść do królestwa Bożego" (Mk 10,25; Mt 19,24; Łk 18,25). Posługuje się hiperbolą, a więc mówi o prawdziwej igle. Ma na myśli jednak nie samo posiadanie bogactw, lecz stosunek człowieka do nich, który nie może być niewolniczym przywiązaniem, niepozwalającym człowiekowi otworzyć się na Boga, jak garb wielbłąda czy obciążający go ładunek dźwigany na grzbiecie. Przypuszczenie, że Jezusowi chodzi o jedną z bram Jerozolimy, tzw. „ucho igielne”, jest błędne, ponieważ bramę tę wzniesiono dopiero w średniowieczu ${ }^{49}$. $\mathrm{O}$ wielbłądzie wspomina Jezus również $\mathrm{w}$ mowie przeciw uczonym $\mathrm{w}$ piśmie i faryzeuszom (Mt 23). Nazywa ich ślepymi przewodnikami, którzy przecedzają komara, a połykają wielbłąda $(23,24)$. Nawiązuje do faryzeuszów, którzy wyławiali z napojów nawet najmniejsze owady, aby uniknąć nieczystości spowodowanej przez martwego owada. Pozostawiają jednak wielbłąda, który uchodził za największe zwierzę lądowe. Piętnuje w ten sposób ich obłudę i hipokryzję ${ }^{50}$.

Jezus, głosząc swoim słuchaczom trudne prawdy o zapoczątkowanym wraz z Jego przyjściem królestwie Bożym, wielokrotnie odwołuje się do świata przyrody. Posługując się powszechnie znanymi obrazami ze świata roślin, zwierząt,

\footnotetext{
47 Por. R. Schnackenburg, dz. cyt. 471n.

48 Por. B. Szczepanowicz - A. MrozeK, dz. cyt. 59n.

49 Tak C.S. KeEner, Komentarz historyczno-kulturowy do Nowego Testamentu, Warszawa ${ }^{2} 2000$, 104.

50 Por. J. Gnilka, Das Matthäusevangelium II 289.
} 
wegetacji, rolnictwa czy klimatu, przedstawia ludziom prawdy, których nie mógłby wyrazić w inny sposób. Dlatego też, głosząc Ewangelię odwołuje się do zwierząt domowych, mówiąc o nich zarówno w znaczeniu realnym, jak i metaforycznym.

\section{Haustiere in der Verkündigung Jesu}

\section{ZUSAMMENFASSUNG}

In seiner Verkündigung des Königsreiches Gottes greift Jesus oft auf ökologische Motive zurück. Gern bedient er sich verschiedener Bilder und Vorstellungen aus der Natur, um zu überzeugen und von seinen Hörern richtig verstanden zu werden. Er spricht auch - realistisch und metaphorisch - von manchen Haustieren, solchen wie: Hund, Schwein, Schaf, Ochs, Bock, Esel und Kamel, um die Wirklichkeit des Königsreiches Gottes zum Ausdruck zu bringen. 